\title{
Technical and Vocational Education and Training: Why Attainment of Kenya's Vision 2030 is an Illusive Goal for TVET Graduates
}

\section{MOTUKA Gideon Mochere ${ }^{1}$ and ORODHO John Aluko ${ }^{2 \star}$}

\author{
'Doctorate Student, Department of Educational Management, Policy and Curriculum Studies, \\ Kenyatta University, Kenya. \\ ${ }^{2}$ Associate Professor of Research and Statistics in Department of Educational Management, \\ Policy and Curriculum Studies, School of Education, Kenyatta University, Kenya.
}

Article No.: 030818035

Type: Research

DOI: 10.15580/GJER.2018.2.030818035

Submitted: 08/03/2018

Accepted: 24/03/2018

Published: $30 / 03 / 2018$

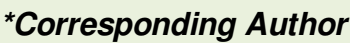

John Aluko Orodho

E-mail: orodhojohn@gmail.com

Keywords: Role, Technical and Vocational Education Training, Graduates, , Vision 2030.
The study examined the role Graduates from Technical and Vocational Education and Training (TVET) towards contributing to the attainment of Vision 2030 in Kenya. The study had two objectives, to determine the perceived importance of TVET and find out the major challenges inhibiting the contribution of graduates from TVET institutions from effectively contributing towards attainment of Kenya's Vision 2030 which is geared towards making Kenya a newly industrialized and middle income country that can provide high quality life for all citizens by the year 2030. The study used 214 participants comprising 38 managers, 72 trainers, and 104 trainees from TVET institutions in Kenya. The Study utilized structured questionnaires, interview guide and observation schedules to collect data. Data was analyzed using descriptive statistics especially the mean and standard deviation and qualitative narrative approaches. The study established that the majority of participants were of the opinion that, graduates from TVET were not well prepared for the Kenyan world of work and had negative attitudes towards informal sector employment opportunities. This negative attitude had hindered trainees from choosing TVET and as such were largely unemployed. The TVET training sector has also suffered from fragmentation and lack of coordination having moved from one ministry to the other over the years. It was evident that, students preferred pursuing technical training at university level, causing a serious imbalance between the Technicians and Engineers. This trend has negatively impacted on the efforts made by the Government of Kenya towards being a newly industrialized country as enshrined in Vision 2030 . The study recommends that, there should be a new paradigm shift in Kenya by reversing this negative attitude among the youth and making overt efforts through appropriate incentives to ensure success of TVET training in the country. 


\subsection{INTRODUCTION}

\subsection{Background to the Study}

It is widely recognised that skills and knowledge are indispensable for employment, social inclusion and job creation, economic and national development, and international competitiveness (Akoojee, 2010; McGrath \& Akoojee 2009; African Union 2007; ILO, 2011) Education and skills training are crucial for improving workers' employability, productivity and inclusiveness of economic growth (ILO, 2011). Consequently, there has been a strong drive in a number of countries for skills development policies (ILO, 2011) transformation in trainees their technical and vocational education and training (TVET) systems (Republic of Kenya, 2012). TVET has attracted attention from both national and international communities (Wanjala Kerre, 1999).

This study contends that, Technical Vocational Education and Training comprises education, training and skill development is a type of training that relates to a wide range of occupational fields, production, services and livelihoods. TVET, as part of lifelong learning, can take place at secondary, posts secondary, and tertiary levels and includes work-based learning and continuing training and professional development which may lead to qualifications (Green,2004). TVET also includes a wide range of skills development attuned to national and local contexts. TVET refers to a range of learning experiences relevant to the world of work and which may occur in various learning contexts including educational institutions and the work place. It also includes learners designed to develop the skills for particular occupations and learning designed, to prepare for entry into the general world work place (Green et-al, 2004). TVET in Kenya encompasses its programs offered in Youth polytechnics, Technical Training Institutes of Technology, National polytechnics andTechnical Universities, that also offer TVET programmes spread across the government. Graduates from TVET institutions are awarded certificate (Abagi \& Ogachi, 2014).

Over the years, independent Kenya has desired to join the developed countries by gradually implementing five - year development plans, but with limited success. To this end, the country unveiled its vision 2030 in the year 2007 after the successful implemention of its Economic Recovery Strategy (ERS) for Wealth and Employment Creation that lasted from 2003 to 2007 (National Economic and Social Council, 2007). A Vision for development is an articulation of desirable future condition or situation which a nation envisages to attain and the plausible course of action taken for such achievement(Abagi \& Ogachi2014). A national vision like that of Kenya, therefore, seeks to actively mobilize people and other sources towards the achievement of shared goals. Indeed, a shared vision arouses people's aspirations and creates the spark that lifts the nation out of the ordinary (Hare, 2007).
The Kenya Vision 2030 is a new long-term development blueprint for for a better society by the year 2030. The aim of the KenyanVision 2030 is to create a globally competitive and prosperous country with a high quality of life by the year 2030 . The Vision aims to transform Kenya into a newly industrialized middle-income country by providing high quality life to all its citizens, in a clean and secure environment (UNESCO, 2007). The Kenya Vision 2030 is a product of a highly participative, consultative and inclusive process that was carried out between October, 2006 and May, 2007. Specifically, the process involved international experts, local experts, ordinary Kenyans and stakeholders from all parts of the country.

The Vision is anchored on three key pillars namely: economics, social and political governance. The economic pillar aims to achieve an average economic growth rate of ten percent (10\%) per annum and sustaining the same till 2030 in order to generate more resources to meet the Sustainable Development Goals (SDGs) and the vision's goals ( United Nations, 2015) . The social pillar seeks to create a just, cohesive and equitable social development in a clean and secure environment. The political pillar aims at raising an issuebased, people-centred, result-oriented and accountable democratic system in the country (Republic of Kenya, 2012). The Kenya Vision 2030 is implemented through five-year medium-term rolling plans, the first of which lasted from 2008 to 2012 and the second one started in 2013 and will end in 2017.

Indeed, the Kenya Vision 2030 that aims at making Kenya a globally competitive and prosperous country by the year 2030 singles out education and training as the levers that will drive Kenya into becoming a middle-income economy. Therefore, Kenya recognizes that, education and training of all Kenyans are fundamental to the success of the Vision is envisaged to play key roles in development. Thus, this study argues that, given the wide trajectory of TVET training, then learning to learn, the development of literacy and numeracy and all life-long skills are integral components of TVET. The overall goal of TVET, therefore is to enable graduates with the much needed skills to fit in the world of work. It was against this background that this study was conceived to determine the challenges hindering graduates from TVET institutions from contributing to the attainment of Vision 2030 in Kenya.

\subsection{The State of Art Review}

Literature abounds which covers the status of Technical and and? Vocational Education and Training (UNESCO,2003; 2013). Terminologies and acronyms referring to Technical and Vocational Education and Training vary from country to country. They include: occupational education (OE), vocational education (VE), professional education (PE), career and technical education (CTE), further education and training (FET), technical and vocational education and training (TVET), 
vocational and technical education and training (VTET), vocational and technical education (VTE), training and further education (TAFE) and vocational education and training (VET) (Wang, 2012; Allais, 2012; Tagicakiverata, 2012). The inconsistencies in referring to this mode of training notwithstanding, UNESCO (2004) recommends the comprehensive term - technical and vocational education and trainingll (TVET) as more appropriate for the sector. UNESCO in 2004 argues that since education and training were complementary parts of preparation for the world of work and should not be perceived as distinct processes, it is reasonable to contend that the terminology should reflect this reality. Technical and vocational education and training (TVET) was, thus, accepted as the more appropriate term. (UNESCO, 2004, p. 2)

The terminology notwithstanding, an effective TVET system requires a functional and responsive TVET policy. Corroborating this, Afeti (2009) argues that development and provision of TVET should begin with policy development, followed by establishment of a central implementation agency. The role of the central implementation agency should be to coordinate, oversee and rationalize all aspects of the TVET sector (COTVET, 2012). The fundamental purpose of TVET provision include acquisition of knowledge, competencies, skills and attitude necessary for employment, job creation and wealth creation and for social, economic and national development (Afeti, 1999). The approach and mode of provision and development of TVET may vary from one country to the other and it may be taught at different educational levels in different TVET institutions (African Union, 2007). Technical and ocational education could be offered in either government controlled or private TVET institutions and, in formal or nonformal sectors (African Union, 2007).

According to a report by the United Nations Education Scientific and Cultural organization (UNESCO, 2003) countries such as Belgium, Poland, Mexico, Bulgaria, Portugal, Thailand, Mauritius, Canada and Ukraine have special provisions for TVET with their societies having good attitudes towards it. Canada has advanced rapidly in the TVET areas as faculties of education in the country offer advanced degree programmed in the study of technology in society and the study of the teaching of technical education(UNESCO,2003). Some innovative methods of instruction have been devised at the Canadian Universities to promote TVET.

Technical courses in Canada at one time taken almost exclusively by males but within the last 15 years an increasing number of females have enrolled in high school and post-secondary school courses (Okello, 2012). In Germany during the 1989/1990 Academic year $50.6 \%$ of students entering vocational courses were female. Similarly, Australia had greatly advanced in TVET education with the overall enrolment clearly explained in the Australian constitution, a document developed in close consultation with training stakeholders throughout Australia (Hart \& Rogojinaru, 2007).

Meanwhile, all the European nations have gone forward to unify the development of TVET by developing a common qualification framework that culminates into all the factors that would sustain any element that might work against the development of education. In order to promote TVET for its importance in the industrial development, the Japanese government gives out career development grants to employers to promote TVET in the country (UNESCO, 2016). The foregoing government policy has promoted both industrial development and TVET education system which in turn has catalyzed the technological and economic development, positioning Japan as one of the most developed countries in the world today. Asians and Africans with its finance coming from the Muslim Community (Abagi \& Ogachi, 2014) will most likely take longer to achieve the objectives of attaining middleincome countries.. All these, were called trade schools and taught subjects like bricklaying, carpentry, machine fittings or motor vehicle mechanics each for three years.

Regionally in Uganda, statistics from the Ministry of labour and social development show that 390,000 (better understood in percent) students who finish tertiary education each year have only 8000 jobs to fight for (Wamakuyu, 2006). Thus, the Uganda government needs to focus on vocational training because it is a short cut to job creation and selfemployment. A stampede for university education which eventually leads to frustration is the therefore, not the best way of addressing Uganda's unemployment problem (Wamukuyu,2006).

In Kenya TVET was introduced in schools by European missionaries during the colonial period. Phelps-Stoke Education Commission Report of 1924 recommended TVET in colonial Kenya leading to the establishment of the Jeans School at Kabete to train African artisans to replace the expensive Indian artisans then. Between 1949 and 1963 more TVET institutions were established in colonial Kenya for Africans. Some of the educational institutions included Thika, Sigalagala, Kwale, Machakos and Eldoret. Mombasa Technical School was established for Arabs, Waswahili were established to offer the much needed skills for the ruralbased economy.

Kenya polytechnic was opened in 1961 with grants from the British government and United Nations Special Fund (Abagi \& Ogachi, 2014). This further expanded opportunities for technical education and training in the country. The polytechnic offers courses in civil, mechanical and electrical engineering, telecommunications, commerce and technical teacher training (Abagi and Ogachi, 2014). TVET remained unpopular with African populations in Kenya and other African countries despite the colonial government's efforts to promote it. This was so because Africans perceived it as a way of preventing meaningful political dialogue and socio-economic competition between 
Africans and Europeans in the labour market (Abagi \& Ogachi, 2014).

TVET has been given a low deal by Africans in Kenya from the colonial period and post-colonial period. In 1981 the Mackay Commission changed Kenyans education system from 7-4-2-3 to 8-4-4. (Republic of Kenya,2010) The A-level in the 7-4-2-3 system of education was accused of not favouring students from marginalized communities in higher education that also led to unemployment. The 8-4-4 system of education was practical skills-oriented curriculum that could lead to self-employment. This system picked well, but practical skills were abolished due to their high demands for facilities and inadequate TVET teachers in Kenya. This gave a further blow to TVET.

\subsection{Statement of Problem}

Despite the fact that TVET is that part of education system that provides courses and training programmes related to employment with a view to enable the transition from basic education institutions to work for young trainees, the number of prospective trainees entering this programmes has been too low thereby making the labour market deficient of competent apprentices. This has implications that the country can hardly boast of having prepared enough critical body of manpower with requisite knowledge, skills, and attitudes relating to various sectors of economic and social life. The cumulative problem is that, Kenya is unlikely to achieve Vision 2030 which requires the country to be a middle-income country by the year 2030 .

Kenya requires among other things technocrats with TVET skills so as to be attained. The Kenya Vision 2030 was launched in the year 2008 and it is to be implemented in five-year plan phases. The first phase lasted from 2008 to 2012 while the second phase is to be implemented from 2013 to 2017.

\subsection{Objectives of the Study}

The overall objective was to find out the role of technical and vocational education in anabling its graduates to meaningfully contribute to the attainment of Vision 2030 in Kenya.There were two specific objectives, namely:

- To investigate the perceived positive attributes of training offered in TVET institutions by managers, trainers and trainees from the institutions.

- To determine the main challenges and bottlenecks hindering graduates from TVET institutions from effectively contributing towards the attainment of Kenya's Vision 2030 in terms of being gainfully employed and wealth creation at household level of the economy.

\subsection{Justification of the Study}

In a number of countries, the need to provide knowledge, attitude and skills necessary for employment, economic, technological and national development has renewed demand for improvement and reform in TVET systems to make them prepare graduates for gainful employment in the formal or informal sector of the economy .. The study has the potential to provide insight for educationists, researchers and policy developers, particularly in Kenya and Africa generally, regarding the policies, practices and experiences of technical and vocational education and training in other countries, which can in turn be used as the a basis for on-going TVET reforms.

\section{RESEARCH METHODOLOGY}

The study employed a combination of secondary desk review and exploratory descriptive survey research design. The combinations of such methodologies have been considered by Orodho, Nzabalirwa, Odundo, Waweru and Ndayambaje (2016) as being appropriate in understanding prevailing situations in institutions of learning and training. The study used 214 participants comprising 38 managers, 72 trainers, and 104 trainees from TVET institutions in Kenya. The Study utilized both structured questionnaires and interview guidelines and observation schedules to collect data. Quantitative data was analyzed using descriptive statistics especially mean(s) and standard deviations. Qualitative data were analyzed using discourse analysis and reported in narrative version. Data were organized and matched with the objectives using bar graphs, pie-charts and direct quotes as suggested by Orodho (2017).

\section{FINDINGS AND DISCUSSION}

\subsection{Positive attributes of TVET Training in Kenya}

The first task of this study was to determine the perceptions of participants regarding some positive attributes of TVET training as an avenue to enable trained graduates get gainful employment. The trainees were requested to state some of their perceived positive attributes of TVET Training in Kenya. Their responses were analyzed and displayed in figure 1.

The most highly positive attribute of TVET training that was cited by nearly one third of all participants $(30.8 \%)$ was the ability of TVET to ensure graduates create employment in the formal and informal sectors of the economy. It was noted that majority of respondents were probably of the opinion that vocational training should lead directly to selfemployment rather than the old perception of finding jobs in already congested formal labour market.

The second highly rated attribute was the current Government of Kenya policy to devolve vocational training to county government level. This would ensure that the trained graduates are retained in 
the local area and make income to circulate in their respective county. The training would also be focused on local market demand.

\section{Positive Attributes of TVET Training in Kenya}

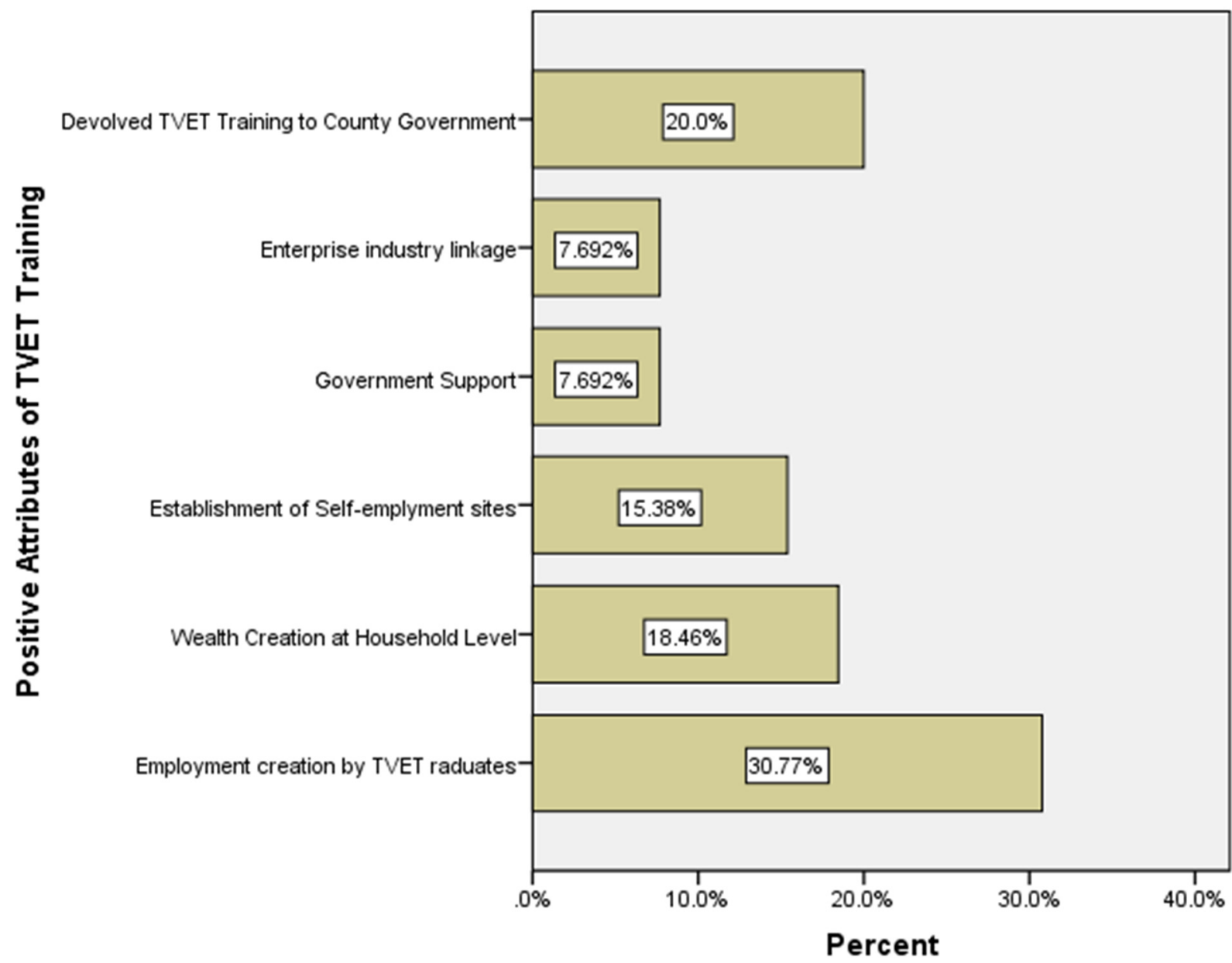

Wealth creation at the household level was also cited by $18.5 \%$ of all participants. The implication is that the training offered at VET institutions should be able to lead the graduates to contribute to wealth in their households and also at county levels. The other positive attributes of TVET training cited were; establishment of market outlets in the local community (15.5\%); as well as the current Government support to revitalize the TVET institutions and training offered (7.7\%) and encouragement of training-industry linkages also at $7.7 \%$. The overall picture painted was that, on paper, there are bright prospects for TVET training and that TVET is the bedrock for Kenya's transformation as intended by the vision.

The interviews conducted with trainers and managers revealed that, as currently designed;
.. there are two major forms of technical and vocational education and training (TVET) in Kenya. The first involved the provision at lower and upper secondary levels, which is generally quite limited following less emphasis on vocational subjects after the logistical challenges of implementing the 8-4-4 education system (Manager: 05 \& Trainer :19)

The second finding involves outside the formal education system that take the form of traditional training offered in technical and vocational institutions or the informal apprenticeships that prepare trainees for trade test such as carpentry, masonry, auto-mechanisms, welding, 
foundry, photography, tailoring, dress-making among others ( Abagi \& Ogachi,2014)

\subsection{Challenges and Bottlenecks in TVET}

The second task for this paper was to profile some of the major bottlenecks encountered in TVET training by graduates. The main challenges cited by participants are summarized in Figure 2.

The most highly cited challenge facing TVE Training generally and TVET graduates, cited by nearly one quarter of all participants, was disparity between the training modules and skill acquisition the targeted to the world of work. The implication is that, the training is not adequately equipping the graduates with requisite skills for self-employment.

The related issue of mismatch between training provided the actual skills required by industries was also cited by about $23 \%$ of all participants. The implication is that the TVET courses have not been crafted to be relevant to the current trends in the labour market which is largely becoming more ICT driven than before. This means that the use of ICT in TVET training has not been well incorporated in the current training modules.

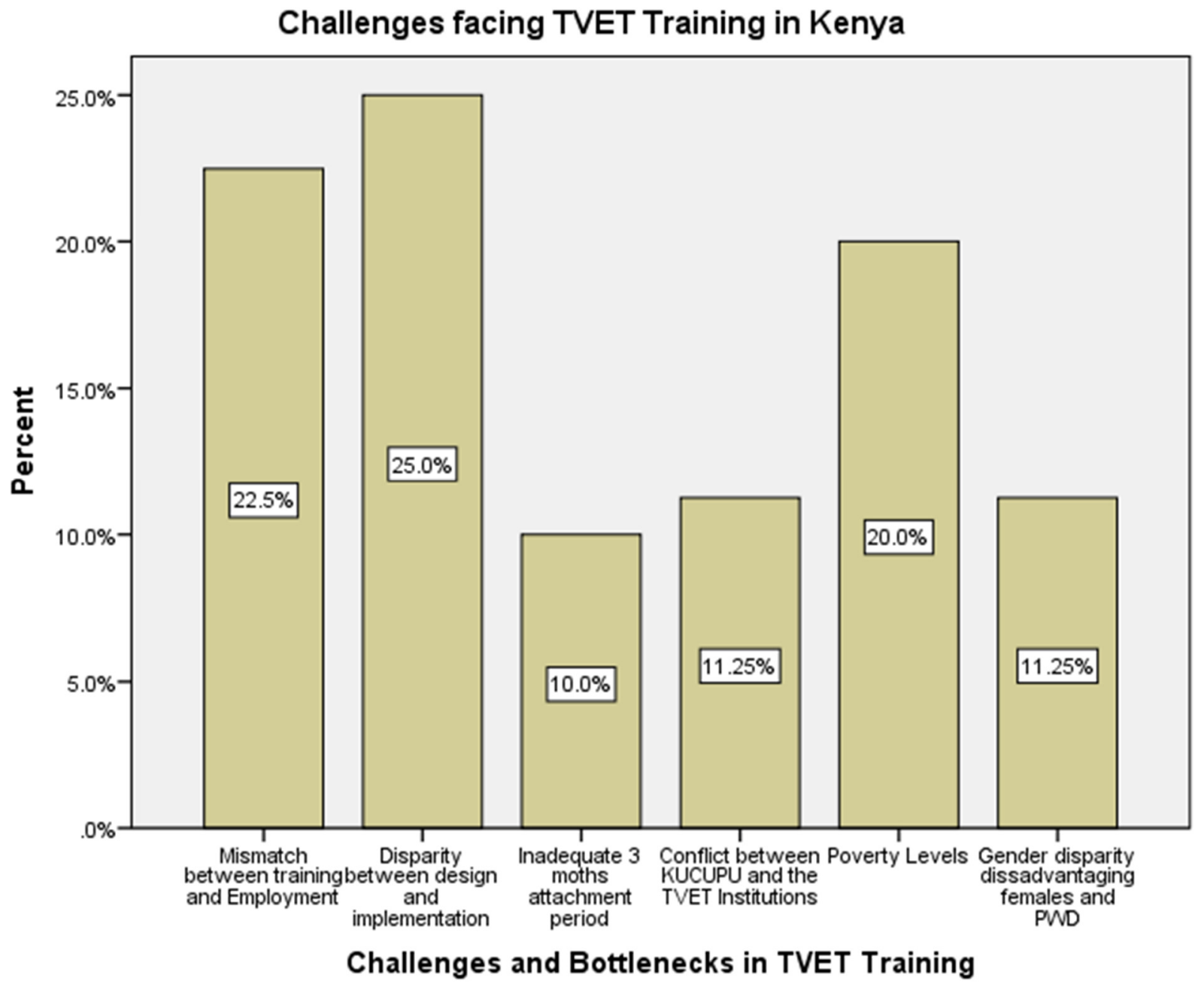

Figure 2: Challenges and Bottlenecks in TVET Training in Kenya

The other challenge facing TVET graduates is poverty which makes them not settle in self-employment ventures that require initial capital to purchase equipment and other resources required to set up a selfemployed venture. It was also noted by several participants during interviews that there was a conflict between the Kenya Universities and Colleges Placement
Unit KUCPU) and the direct recruitment by TVET institutions. It is apparent that national placement unit is more concerned with placing students in degree, diploma and certificate courses, while, the latter is focused on vocational artisan training. The other challenge was that, the trainees felt that the three months attachment period into industry or apprenticeship 
was rather short. The implication is that they needed more time to get hands-on experience in a workplace setting.

The interviews with managers and trainers also revealed that:

The responsibility of curricula and related institutional, materials for TVET in Kenya is in the hands of Kenya Institute of Curriculum Development (KICD). To facilitate TVET curriculum Development, KICD structures its curriculum panels to include broad representation of key stakeholders who include private, industry employers in technical and occasional training. Most times private employers do not effectively participate in KICD panel discussions and their views tend to be peripheral in curricula decision making (Manager 04, 07 \& trainer, 14).

Consequently, there is a serious mismatch between the traditional analogue approaches in technology in TVET institutions and the more modern technology in industry. Time in TVET curricula designed to reflect a balance between practical activities and the inculcation of theory as shown in the table below in percentages.

Table 1: Percentage of time allocated in TVET programmes

\begin{tabular}{llll} 
Programme level & Practical & Theory & Total \\
\hline Artisan & 90 & 10 & 100 \\
\hline Craft & 80 & 20 & 100 \\
\hline Technician & 60 & 40 & 100 \\
\hline Technologist & 30 & 70 & 100 \\
\hline Advanced Technologist & 20 & 80 & 100
\end{tabular}

It can be inferred from Table 1 above that the highest proportion of time in TVET institutions is allocated to artisan and craft courses, where graduates are expected to be the operatives on the workshop floor. Time allocated to the theory component progressively increases in technician and technologist courses, whose graduates are expected to have design and supervisory responsibilities.

Due to the fact that TVET programmes are geared to hands on production, there is more curriculum prescribed periods for exposure to specific industries and business attachment. Such exposure enables TVET trainees to acquire practical experience through observation and participation in production activities. (Abagi and Ogachi 2014). Indeed, the strengthened partnership between industry and TVET institutions will provide a platform to ensure relevance and quality of training and curriculum development (Rep of Kenya, 2012)

Some managers of TVET institution made an input on policy direction by stating that:

"Like other education sub-sectors, TVET has undergone policy changes intended to regulate and fit the sector into national development objectives. For instance, in 2012, the government passed the TVET bill to regulate the TVET sector but provided autonomy to TVET institutions as a way of enhancing flexibility in TVET programmes. The bill aimed to creat a robust and comprehensive TVET policy focusing on strategies for expansion to halt the current decline and transformation in higher education institutions and universities and increase in enrolments, funding as well as modernizing training programmes to realign them with industry (Manager 01, 07).

The 2012 bill categorized offering TVET to provide a hierarchy, by category and by level so as to create a clear TVET path as per policy which include;

a) Primary school

b) Vocation training centre (VTC)

c) Technical college

d) Technical teachers training college (TTTC)

e) National Polytechnic (NP)

f) Technical University (TU).

The above results are supported by previous literature which indicate that although TVET has been cited both as a system for developing skills and competencies necessary for socio-economic development, national development, employment and job creation (Ansah \& Ernest, 2013) and as a mechanism for poverty alleviation, self-employment and wealth creation (UNESCO, 2003; Ansah \& Ernest, 2013), it has also been negatively perceived in various ways (African Union, 2007; Shah et al., 2011; Ayalew, 2011; 3 Killian et al., 2009; Osuji, 2003), mainly as a consequence of poor policy and poor implementation. McGrath (2005) indicates that students and other TVET stakeholders consider low prestige as among the critical lingering challenges bedeviling the TVET sector. In South Africa, TVET has been negatively perceived (RSA, 2008).

The concern regarding disparity between design of TVET training modules and skill acquisition was also cited by a study in Ghana which contended that the sector has been held in low esteem (COTVET, 2012). TVET systems have been criticized for using outdated curriculum and facilities, inadequate teaching and 
supporting staff, and for offering programmes that do not respond to market and industry requirements (McGrath, 2005; Yihunie, 2011; African Union, 2007; Osuji, 2003). Negative perceptions such as these could be attributed to poor TVET policy which too often relegates the sector to least desired status in the overall education system in many countries (Boateng, 2010).

Interview conducted with TVET practitioners of technical and vocational education and training indicated that, although, the role of quality assurance system has been recognized, it has not been implemented in the TVET sector. They averred that:

"Because technical and vocational education
is provided by different departments and
organizations including private sectors,
maintaining quality is a challenge to the
council but we are working towards
establishing a strong monitoring and
evaluation units in the system for this
purpose" (Participant 5: Manager \& Trainer
$02,09,15)$.

The implication of the cited responses revealed that in practice, quality assurance mechanisms have not been put in place in the technical and vocational education and training system. According to the participants, setting up monitoring and evaluation department would be necessary for improving the quality of technical and vocational education and training.

The overall revelation of the study, which is supported with literature, is that the TVET sector has suffered from fragmentation and lack of coordination (Yihunie, 2011). A number of authors in the literature (Atchoarena \& Delluc, 2001; Oketch, 2007; Bose, 2008; African Union, 2007) note that TVET can be a dead end if not backed by research-based decision making processes. Failure of TVET programmes has been attributed to poor planning and also wrong selection of planning personnel (Usman \& Pascal, 2009), exacerbated by lack of policy and poor implementation (UNESCO, 2008). Circumstances such as the ones found in this study point to the need for comparative research for policy reform, policy development, policy formulation and system transformation.

The mismatch between skill training and employment was also found in the recommendations from Engineers Registration Board (ERB) of Kenya ${ }^{\wedge}$ estimates that Kenya had about 6,350 engineers in 2010, which served 40 million people then. It furthers states that Kenya will have a population of 60 million by 2030 that will require 30,000 engineers and engineering technologists. This number of engineers in Kenya is low given that the ratio of TVET technocrats in developed countries is 1:2:4:16 in relation to engineer, technologist, technicians, craft-people and artisan.

Some TVET practitioners interviewed summarized the bottlenecks in the TVET when they averred that:
“...... the system has a very poor track record and suffers from lack of recognition, underfunding, poor public perception of the sector, lack of adequate learning facilities and lack of qualified staff and inadequate training. This policy learning however has to proceed with caution as this study revealed that TVET policy variants appear to be located in multiple documents and managed by different ministries over the years which may present challenges for practitioners" (Managers: 1,7,9, \& T12).

\section{CONCLUSION AND RECOMMENDATIONS}

\subsection{Conclusons}

The study concluded that despite the noble rationale for establishing TVET institutions, the TVET policy implementations is poor in Kenya and the system has failed in providing the much-needed skills required for employment, economic and national development. There was enough evidence to conclude that graduates of technical and vocational education and training were poorly trained and are not responsive to the needs of the Kenyan labour market. The technical and vocational education and training sector is bedeviled by numerous challenges, which include: negative attitude towards vocational training and jobs in the informal sector, underfunding of vocational institutions, inadequate teaching and learning facilities, and poor governance. Other serious challenges facing the sector included inadequate qualified personnel and poor public perception and implementation of the sector.

From the standpoint of practitioners' experiences of technical and vocational education and training, it is further concluded that, the system has a very poor track record and suffers from lack of recognition, under-funding, poor public perception of the sector, lack of adequate learning facilities and lack of qualified staff and inadequate training.

\subsection{Recommendations}

From the results, discussion and conclusions made, the following recommendations are made:

1. The Kenya national government needs to support TVET needs to continue to be intensified so as to achieve the intended aspects of the Kenya Vision 2030.

2. The national government needs to further increase budgetary allocations to TVET institutions so as to equip them with the required instructions and equipment to enhance training of human resources for the full attainment of the intended vision.

3. The national government of Kenya as well as County Governments need to construct and adequately equip at least 130 TVET institutes 
since the current TVET institutes are far too low to produce adequate skilled personnel required for the attainment of Vision 2030.

4. Youth polytechnics and home crafts that are under County Governments need to be meaningfully structured or instead transferred to the national Kenya government or central government so as to be run efficiently and effectively to produce the deserved results towards the Kenya Vision 2030.

5. TVET instructors need to be sponsored by the national government for further training ^to learn advanced skills and impart them to TVET trainees in Kenya for optimum attainment of the Vision 2030.

6. TVET Trainers should have adequate skills, Experience and exposure to modern technology and industry.

\section{REFERENCES}

Abagi, O. \& Ogachi, O. I. (2014). Fifty Years of Education Development in Kenya: Challenges Prospectus for the Future. Nairobi; Jomo Kenyatta Foundation.

Abubakar, M., Kazaure, M., \& Yusuf, S. (2013). Introducing the NVQF for more open and flexible skills domain in Nigeria.

African Union (2007). Strategy to revitalize Technical and Vocational and Training in Africa. Retrieved on Octover $22^{\text {nd }}, 2011$.

Afeti, G. (2009). Technical and vocational education and training for industrialization.

African Union. (2006). Second decade of education for Africa (2006-2015), draft plan of action. Addis Ababa: African Union. Retrieved November 4, 2013

Akoojee, S. (2012). Skills for inclusive growth in South Africa: Promising tides amidst perilous waters. International Journal of Educational Development, 32(5), 674-685.

Allais, S. (2012). Will skills save us? Rethinking the relationships between vocational education, skills development policies, and social policy in South Africa. International Journal of Educational Development, 32(5), 632-642. doi: 10.1016/j.ijedudev.2012.01.001

Ansah, S. K., \& Ernest, K. (2013). Technical and vocational education and training in Ghana: A tool for skill acquisition and industrial development. Journal of Education

Atchoarena, D., \& Delluc, A. (2001). Revisiting technical and vocational education in sub-Saharan Africa: An update on trends innovations and challenges. International Institute for Educational Planning: Paris.

Atchoarena, D., \& Delluc, A. (2002). Revisiting technical and vocational education in sub-Saharan Africa: An update on trends, innovations and challenges. Retrieved January 1, 2014, from http://unesdoc.unesco.org/images/0012/001293/129 354e.pdf

Boateng, F. B. (2010). The state of the textiles training and its impact on Recidivism in the Kumasi Central Prison.

Bose, D. (2008). Innovative approach of TVET linkage An Indian experience. In Final Report of International Forum on Vocational-Technical Education: Policy Framework, Innovative Practices and International Partnership in conjunction with Seminar on the Reform of the Engineering Education, 43-53. http://www.inruled.org/a/soft/101125/Final-reportTVET.pdf

ILO. (2011). Skills for employment policy brief: Formulating a national policy on skills development. Geneva: International Labour Office. Retrieved from http://www.ilo.org/wcmsp5/groups/public/---ed_emp/-- ifp skills/documents/publication/wcms 167172.pdf

Killian, L. M., Tendayi, L. G., \& Augustine, L. T. (2009). An assessment of partnerships between technical vocational education and training and its stakeholders in the development of Ethiopian SMEs. Economia. Seria Management, 12(2), 39-56.

McGrath, S., \& Akoojee, S. (2007). Education and skills for development in South Africa: Reflections on the accelerated and shared growth initiative for South Africa. International Journal of Educational Development, 27(4), 421-434.

McGrath, S. (2005). Key Issues and challenges for transformation. In S. Akoojee, A. Gewer \& S. McGrath (Eds.), Vocational education and training in Southern Africa: A comparative study (pp. 139-151). Cape Town: HSRC Press.

McGrath, S., \& Akoojee, S. (2009). Vocational education and training for sustainability in South Africa: The role of public and private provision. International Journal of Educational Development, 29(2), 149-156. doi: 10.1016/j.ijedudev.2008.09.008

MOEST (2012). Technical and Vocational Education and Training (TVET) Policy. Nairobi: Government Printer. MOEST (2014). Education for All 2015 National Review. Nairobi: Government Printer.

Oketch, M. O. (2007). To vocationalise or not to vocationalise? Perspectives on current trends and issues in technical and vocational education and training (TVET) in Africa. International Journal of Educational Development, 27(2), 220-234. doi: http://dx.doi.org/10.1016/j.ijedudev.2006.07.004

Osuji, F. (2003). TVET and human resources development: A panacea for national development. Final report of the Sub-Regional Seminar for West Africa. In N. A. Yakubu \& S. N. Mumah (Eds.), Implementing the UNESCO/ILO Recommendations Concerning TVET. Kaduna: UNESCO.

Okoye, K., \& Okwelle, P. (2013). Complex mix of sociopolitical synergy on technical vocational education and training (TVET) in Nigeria. Kuwait Chapter of Arabian Journal of Business and Management Review, 3(3), 28-40. 
Republic of Kenya (2012). Sessional Paper No. 14 of 2012 of Reforming, Education and Training in Kenya. Nairobi: Government Press.

Republic of South Africa (RSA). (2008a). Accelerated and Shared Growth Initiative for South Africa: Annual Report 2008. Retrieved March 26, 2015, from

http://www.gov.za/sites/www.gov.za/files/asgisa2008 .pdf

Republic of South Africa (RSA). (2008b). Joint Initiative on Priority Skills Acquisition: Report on Activities in 2007. Retrieved April 8, 2015, from http://unpan1.un.org/intradoc/groups/public/docume nts/cpsi/unpan030283.pdf

Republic of South Africa (RSA). (2010). Growing priority skills in South Africa: Final report on JIPSA. Retrieved April 8, 2015, from http://www.hrdcsa.org.za/sites/default/files/document s/Consolidated\%20JIPSA\%20 close\%20out\%20report_0.pdf

Korean Institute (2005). Technical Vocational Education Manual. Korean Institute of TVET Publication.

Shah, I. H., Ajmal, M., Rahman, F., \& Akhter, M. N. (2011). A comparative study on vocational training structure of Pakistan with British and German model. International Journal of Business and Social Science, 2(1), 162-169.

Shamim, M., Huq, R., Aktaruzzaman, M., \& Clement, C. K. (2011). Factors influencing use of ICT in technical \& vocational education to make teaching-learning effective \& efficient: Case study of polytechnic institutions in Bangladesh. International Journal of Basic \& Applied Sciences, 11(3).

Tagicakiverata, I. W. (2012). TVET in Fiji: attitudes, perceptions and discourses. NOVA. The University of Newcastle's Digital Repository. doi: http://hdl.handle.net/1959.13/933439
Talabi, A. S. (2012). Employee's training and development for optimum productivity: The role of Industrial Training Fund (ITF), Nigeria. Developing Country Studies, 2(4), 50- 58.

UNESCO (2003). Report on Technical, Vocation, Education and Training. New York: USA.

Mjelde L. \& Daly (2006). Working Knowledge in a Globalising World: From Working to Learning from Learning to Work (pp 83-104). Bern: Peter Lang.

UNESCO (2004). International Meeting on Innovation and Excellence in TVET Teacher / Trainer.

UNESCO - UNEVOC (2007). Participation in Formal Technical and Vocational Education and Training Programmes World Wide. An Initial Statistical Study. Paris: UNESCO.

Hart, J and Rogojinaru, A. (2007). The Development of National Qualifications and Quality Assurance Frameworks in the Context of the TVET Reform in Romania. European Journal of Education p 24:4.

Wang, S. (2012). The legal frameworks of technical and vocational education and training (TVET) from international level to national level of China. (Master's thesis, Lund University, Lund, Sweden). Retrieved from http://lup.lub.lu.se/luur/download?func=downloadFile \& recordOld $=2970828 \&$ fileOld $=3044839$

Wanjala Kerre, B. (1999). The role and potential of technical and vocational education in formal education systems in Africa. Enterprise in AfricaBetween poverty and growth, 1(19), 202-210.

Womakuyu, F. (2010). Unemployment, a Time Bomb in the New Vision News Paper November 282010. New Vision Publication Ltd.

Yihunie, H. (2011). The challenges of technical vocational education and training colleges in Benshangul Gummuz Regional State. (Master's thesis, Addis Ababa University, Addis Ababa, Ethiopia).

Cite this Article: Motuka G.M. and Orodho J.A. (2018). Technical and Vocational Education and Training: Why Attainment of Kenya's Vision 2030 is an Illusive Goal for TVET Graduates. Greener J Edu Res, 8(2): 07-16, http://doi.org/10.15580/GJER.2018.2.030818035. 